\title{
HUBUNGAN OBESITAS DENGAN KEJADIAN HIPERTENSI PADA USIA DEWASA
}

\author{
Tisna Yanti,* Nining Fitrianingsih, Ainul Hidayati \\ Sekolah Tinggi Ilmu Kesehatan Wijaya Husada Bogor \\ J1. Letjend Ibrahim Adjie No. 180, Sindang Barang, Bogor Barat, 16117, Indonesia \\ *)E-mail: tisnayantiabas@yahoo.com
}

Diterima: Januari 2018, diterbitkan: April 2018

\begin{abstract}
ABSTRAK
Tujuan Penelitian: mengetahui hubungan antara obesitas dengan kejadian hipertensi pada usia dewasa. Metode: Desain penelitian yang digunakan adalah analisis korelasional dengan pendekatan cross sectional. Sampel dalam penelitian ini adalah 53 responden yang diambil dengan teknik aksidental sampling. Kriteria inklusi sampel adalah pasien dewasa yang mengalami hipertensi dan bersedia menjadi responden. Pengambilan data dilakukan pada bulan September-Desember 2017. Instrumen penelitian menggunakan alat pengukur tinggi badan dan berat badan (timbangan digital) untuk menilai obesitas dan untuk mengukur tekanan darah digunakan tensi meter digital dengan hasil berpatokan pada JNC-VII. Uji statistik yang digunakan dalam penelitian ini adalah uji koefisien korelasi creamer. Hasil: Hasil penelitian menunjukkan dari 53 responden, sebanyak 34 (64,2\%) responden mengalami obesitas dan 42 (79,2\%) responden mengalami hipertensi. Hasil penelitian menunjukkan nilai uji statistik dengan nilai $p$ value $=0,031(<0,05)$, hal ini menunjukkan ada hubungan obesitas dengan kejadian hipertensi pada usia dewasa, di mana nilai $\mathrm{OR}=4,375$, yang artinya pasien dewasa akan beresiko atau berpeluang mengalami hipertensi sebanyak 4,375 kali. Diskusi: seseorang yang mengalami obesitas akan terjadi resistensi insulin dan hiperinsulinemia sehingga akan meningkatkan aktivitas syaraf simpatis dan sistem rennin angiotensin yang berperan meningkatkan tekanan darah (hipertensi). Kesimpulan: Seseorang yang mengalami obesitas akan beresiko mengalami penyakit hipertensi.
\end{abstract}

Kata Kunci: Obesitas, hipertensi, usia dewasa

\section{CORRELATION BETWEEN OBESITY AND HYPERTENSION IN ADULTHOOD} ABSTRACT

Objective: To identify the correlation between obesity and incidence of hypertension in adulthood. Methods: The research employed correlational analysis design with cross sectional approach. Samples were taken accidental sampling technique with a sample size of 53 respondents. The sample inclusion criteria were adult patients who had hypertension and were willing to be respondents. Data were collected in September-December 2017. The research used height and weight measuring instruments (digital scale) to assess obesity and digital tension meter of which results were based on JNCVII to measure blood pressure. The statistical test was performed using Cramer's correlation coefficient test. Results: The results showed that out of 53 respondents, 34 respondents (64.2\%) were obese and 42 respondents (79.2\%) had hypertension. The research results showed that the value of statistical tests was p value of $0.031(<0.05)$, indicating that there was a correlation between obesity and incidence of hypertension in adulthood, where OR value was 4.375, meaning that adult patients were 4,375 times likely to be at risk or have the chance to have hypertension. Discussion: An obese person will develop insulin and hyperinsulinemia resistance which will increase the activity of sympathetic nerves and renin-angiotensin system which plays a role in increasing blood pressure (hypertension). Conclusion: An obese person will be at risk of having hypertension.

Keywords: Obesity, hypertension, adulthood 


\section{LATAR BELAKANG}

Hipertensi saat ini masih menjadi masalah utama di dunia. Menurut Joint National Committee on Prevention, Detection, Evaluation, and Treatment on High Blood Pressure VII (JNC-VII), hampir 1 milyar orang menderita hipertensi di dunia (Chobanian, et al., 2003). Menurut laporan Badan Kesehatan Dunia atau WHO, hipertensi merupakan penyebab nomor 1 kematian di dunia (World Health Organization Regional Office for South-East Asia, 2011). Data tahun 2010 di Amerika Serikat menunjukkan bahwa $28,6 \%$ orang dewasa berusia 18 tahun ke atas menderita hipertensi (Chobanian et al., 2003).

Data AHA (American Heart Association) tahun 2010, di Amerika tekanan darah tinggi ditemukan satu dari setiap tiga orang atau 65 juta orang dan 285 atau 59 juta orang mengidap hipertensi dan ironinya semua orang yang mengidap hipertensi hanya satu pertiganya saja yang mengetahui keadaan penyakitnya dan hanya $61 \%$ yang melakukan pengobatan. Dari penderita yang mendapat pengobatan hanya satu per tiga yang mencapai target tekanan darah optimal atau normal (Lloyd-Jones, et al., 2010).

Angka kejadian hipertensi berdasarkan Riset Kesehatan Dasar (Riskedas) Kementerian Kesehatan Republik Indonesia tahun 2013 mencapai sekitar 25,8\% (Kementerian Kesehatan Republik Indonesia, 2013b). Data hipertensi di Jawa Barat mencapai $29,4 \%$ dari seluruh jumlah penduduk usia $\geq 18$ tahun (Kementerian Kesehatan RI, 2013a). Data hipertensi di kota Bogor pada tahun 2015 yaitu sekitar 6,4\% dari jumlah penduduk yang menderita hipertensi (Dinas Kesehatan Provinsi Jawa Barat, 2016). Sedangkan dari data Puskesmas Sindang Barang Kota Bogor yang dilihat oleh peneliti satu tahun terakhir pada tahun 2016, didapat data penderita dengan hipertensi sebanyak 177 orang.

Faktor-faktor yang sering menyebabkan hipertensi adalah faktor keturunan, umur, jenis kelamin dan ras, stres, gaya hidup yang kurang baik, dan obesitas (Junaedi et al., 2013). Obesitas (kegemukan) yaitu ketidakseimbangan antara jumlah makanan yang masuk dibandingkan dengan pengeluaran energy oleh tubuh atau suatu keadaan dari akumulasi lemak tubuh yang berlebihan di jaringan lemak suatu organ tertentu. Semakin besar massa tubuh seseorang maka akan semakin banyak darah yang dibutuhkan untuk menyuplai oksigen dari nutrisi ke otot dan jaringan lain. Obesitsa bisa meningkatkan jumlah panjangnya pembuluh darah sehingga dapat meningkatkan resistensi darah yang seharusnya mampu menempuh jarak lebih jauh dan tekanan darah akan menjadi tinggi (Sani, 2008).

Berdasarkan persoalan-persoalan hipertensi di atas maka dari itu peneliti tertarik untuk melakukan penelitian tentang "Hubungan obesitas dengan kejadian penyakit hipertensi pada usia dewasa di Puskesmas Sindang Barang Kota Bogor."

\section{METODE}

Desain penelitian yang digunakan adalah analisis korelasional dengan pendekatan cross sectional (Notoatmodjo, 2010). Lokasi penelitian ini di Puskesmas Sindang Barang Kota Bogor. Populasi penelitian ini adalah pasien dewasa (usia 26-45 tahun) yang mengalami hipertensi pada 1 tahun terakhir (2016) berjumlah 177 orang. Sampel dalam penelitian ini diambil $30 \%$ dari populasi sehingga dihasilkan jumlah sampelnya adalah 53 orang (Arikunto, 2010). Teknik pengambilan sampel dengan cara accidental sampling dengan kriteria inklusi pasien 
dewasa yang mengalami hipertensi dan bersedia menjadi responden. Pengambilan data dilakukan pada bulan SeptemberDesember 2017.

Instrumen dalam penelitian ini dengan lembar observasi dan pengukuran menggunakan alat pengukur tinggi badan dan berat badan (timbangan digital) yang sudah dikalibrasi dan digunakan selama penelitian berlangsung untuk semua responden penelitian.

Obesitas ditentukan berdasarkan Indeks Massa Tubuh (IMT), yaitu jika nilai IMT $\geq 30 \mathrm{~kg} /$ $\mathrm{m}^{2}$ maka dikatakan obesitas, dan jika IMT <30 $\mathrm{kg} / \mathrm{m}^{2}$ maka tidak obesitas. Untuk mengukur tekanan darah digunakan tensi meter digital dengan hasil berpatokan pada JNC-VII, yaitu dikatakan mengalami hipertensi jika tekanan darah sistolik $\geq 140 \mathrm{mmHg}$ dan Tekanan darah diastolik $\geq 90 \mathrm{mmHg}$.
Pada saat pengambilan data penelitian, dijelaskan tujuan penelitian terlebih dahulu kepada responden dan bagi responden yang bersedia maka akan mengisi inform consent. Setelah itu responden diukur tinggi badan dan berat badan dengan menggunakan timbangan digital untuk menentukan IMT dan mengukur tekanan darah dengan menggunakan tensi meter digital. Uji statistik yang digunakan adalah uji koefisien korelasi cramer.

\section{HASIL PENELITIAN}

\section{Karakteristik Responden}

Berdasarkan data karakteristik responden penelitian, dari 53 responden diperoleh ratarata responden berumur $>40$ tahun $(69,8 \%)$, sebanyak $84,9 \%$ di antaranya berjenis kelamin perempuan, dan $88,7 \%$ dengan riwayat bukan perokok.

Tabel 1. Distribusi frekuensi obesitas dan kejadian hipertensi pada usia dewasa $(n=53)$

\begin{tabular}{lcc}
\hline Variabel & Frekuensi & $\begin{array}{c}\text { Persentase } \\
(\%)\end{array}$ \\
\hline Obesitas & & \\
\hline Tidak obesitas & 19 & 35,8 \\
Obesitas & 34 & 64,2 \\
Kejadian Hipertensi & & \\
Hipertensi & 42 & 79,2 \\
Non hipertensi & 11 & 20,8 \\
\hline
\end{tabular}

Berdasarkan Tabel 1 dapat dilihat dari 53 responden didapatkan 34 responden (64,2\%) mengalami obesitas dan 42 responden $(79,2 \%)$ mengalami hipertensi.

Tabel 2. Hubungan Obesitas dengan Kejadian Hipertensi pada Pasien Usia Dewasa ( $n=53)$

\begin{tabular}{|c|c|c|c|c|c|c|}
\hline \multirow{3}{*}{ IMT } & \multicolumn{4}{|c|}{ Kejadian } & \multirow{3}{*}{$p$ value } & \multirow{3}{*}{ OR $(95 \% \mathrm{CI})$} \\
\hline & \multicolumn{2}{|c|}{ Tidak Hipertensi } & \multicolumn{2}{|c|}{ Hipertensi } & & \\
\hline & $n$ & $\%$ & $n$ & $\%$ & & \\
\hline Tidak obesitas & 7 & 36,8 & 12 & 63,2 & \multirow{2}{*}{0,031} & 4.375 \\
\hline Obesitas & 4 & 11,8 & 30 & 88,2 & & $(1.080-17.724)$ \\
\hline Jumlah & 11 & 20,8 & 42 & 79,2 & & \\
\hline
\end{tabular}




\section{Hubungan Obesitas dengan Kejadian Hipertensi pada Usia Dewasa}

Berdasarkan tabel 2, terdapat 30 responden $(88,2 \%)$ yang mengalami obesitsa dan hipertensi. Hasil uji statistik didapatkan nilai $p$ value 0,031 yang artinya ada hubungan antara obesitas dengan kejadian hipertensi, nilai OR-nya yaitu 4.375 yang artinya pasien dewasa akan beresiko atau berpeluang mengalami hipertensi sebanyak $4.375 \approx 4$ kali dibandingkan pada pasien yang bukan dewasa.

\section{DISKUSI}

Penelitian ini menunjukkan sebanyak 34 responden $(64,2 \%)$ mengalami obesitas dan 42 responden $(79,2 \%)$ mengalami hipertensi. Hal ini sejalan dengan hasil penelitian yang dilakukan oleh Natalia, Hasibuan, \& Hendro (2014) yang melaporkan bahwa sebanyak 113 responden $(55,4 \%)$ mengalami obesitas dan 64 responden $(56,6 \%)$ mengalami hipertensi.

Penyakit hipertensi merupakan peningkatan tekanan darah yang memberi gejala berlanjut untuk suatu organ target, seperti stroke untuk otak, gagal ginjal untuk organ ginjal, dan penyakit jantung koroner untuk pembuluh darah jantung. Penyakit ini telah menjadi masalah utama bagi negara berkembang maupun negara maju di dunia dan sebagian besar kasus hipertensi tidak ada terapi definitive tapi dapat di kontrol dengan pola hidup sehat dan medikasi (Sani, 2008).

Hipertensi adalah kondisi medis dimana terjadi peningkatan tekanan darah secara kronis (dalam jangka waktu lama), tekanan darah yang melebihi $140 / 90 \mathrm{mmHg}$ saat istirahat diperkirakan mempunyai tekanan darah tinggi. Secara umum orang dengan hipertensi terlihat sehat dan sebagian besar tidak menimbulkan gejala, tetapi ada pula gejala awal yang bisa timbul dari hipertensi antara lain sakit kepala, perdarahan dari hidung, pening, wajah kemerahan dan kelelahan. Sedangkan gejala yang ditimbulkan oleh hipertensi berat menahun biasanya meliputi sakit kepala, kelelahan, mual muntah, sesak nafas, gelisah, pandangan kabur jika sudah terjadi kerusakan pada otak, mata, jantung, dan ginjal serta penurunan kesadarah bahkan koma (Sustrani, Alam, \& Hadibroto, 2004).

Perlindungan terbaik untuk mengatasi komplikasi akibat hipertensi adalah dengan mencegah, mendeteksi secara dini dengan memeriksa atau mengontrol secara rutin. Faktor-faktor yang sering menyebabkan hipertensi termasuk di antaranya adalah obesitas (Junaedi et al., 2013).

Berat badan merupakan faktor determinan pada tekanan darah pada kebanyakan kelompok etnis di semua umur. Prevalensi tekanan darah tinggi pada dewasa dengan IMT $>30 \mathrm{~kg} / \mathrm{m}^{2}$ (obesitas) adalah $38 \%$ untuk pria dan $32 \%$ untuk wanita. Sedangkan pada dewasa dengan IMT $<25 \mathrm{~kg} / \mathrm{m}^{2}$ (status gizi Normal) adalah 18\% untuk pria dan 17\% untuk wanita (World Health Organization Regional Office for South-East Asia, 2011).

Obesitas merupakan faktor resiko lain yang turut menentukan terjadinya hipertensi. Semakin besar massa tubuh seseorang maka akan semakin banyak darah yang di butuhkan untuk menyuplai oksigen dan nutrisi ke otot dan jaringan lain. Obesitas bisa meningkatkan jumlah panjangnya pembuluh darah sehingga dapat meningkatkan resistensi darah yang seharusnya mampu menempuh jarak lebih jauh dan tekanan darah akan menjadi tinggi, kondisi ini juga dapat diperparah oleh adanya sel-sel jaringan lemak yang memproduksi senyawa merugikan bagi jantung dan pembuluh darah. Pada seseorang dengan obesitas juga akan terjadi resistensi insulin dan hiperinsulinemia sehingga akan meningkatkan aktivitas syaraf 
simpatis dan sistem renin angiotensin yang berperan meningkatkan tekanan darah (hipertensi) (Guyton \& Hall, 2010/2014).

Diperlukan penelitian lanjut dengan dilakukannya pengendalian terhadap faktor confounding lainnya, seperti usia, jenis kelamin, dan riwayat merokok, sehingga hasil yang didapatkan benar-benar faktor murni yang memengaruhi hipertensi.

\section{SIMPULAN}

Usia dewasa yang mengalami obesitas akan beresiko mengalami penyakit hipertensi. Diharapkan masyarakat meningkatkan kegiatan positif, seperti olahraga dan menjaga pola makan sebagai salah satu upaya untuk mencegah terjadinya hipertensi.

\section{DAFTAR PUSTAKA}

Arikunto, S. (2010). Prosedur penelitian suatu pendekatan praktik. Jakarta: Rineka Cipta.

Chobanian, A. V., Bakris, G. L., Black, H. R., Cushman, W. C., Green, L. A., Izzo, J. L., Jones, D. W., ..., the National High Blood Pressure Education Program Coordinating Committee. (2003). The seventh report of the joint National Committee on prevention, detection, evaluation, and treatment of high blood pressure. Hypertension, 42:1206-1252.

Dinas Kesehatan Provinsi Jawa Barat. 2016. Profil kesehatan Provinsi Jawa Barat tahun 2015. Retrieved from http://www.depkes.go.id/resources/.../ profil/PROFIL...PROVINSI_2015/12 Jabar 2015.pdf

Guyton, A. C., \& Hall, J.E. (2014). Guyton and Hall textbook of medical physiology (Twelfth Edition). (Alih Bahasa: Ilyas, E. I. I). Jakarta: EGC. (Buku asli diterbitkan 2010).

Junaedi, E., Yulianti, S., Rinata, M. G. (2013). Hipertensi kandas berkat herbal.
Jakarta: FMedia.

Kementerian Kesehatan Republik Indonesia. (2013a). Hipertensi. Jakarta: Pusat Data dan Informasi Kementrian Kesehatan RI.

Kementerian Kesehatan Republik Indonesia. (2013b). Riset kesehatan dasar nasional. Jakarta: Badan Penelitian dan Pengembangan Kesehatan Kementerian Kesehatan Republik Indonesia.

Lloyd-Jones, D., Adams, R. J., Brown, R. J., Carnethon, M., Dai, S., Simone, G. D., Ferguson, T. B., ...Wylie-Rosette, J. (2010). Heart disease and stroke statistics-2010 update: A report from the American Heart Association. Circulation, 121(7): e46-e215.

Natalia, D., Hasibuan, P., Hendro. (2014). Hubungan obesitas dengan kejadian hipertensi di Kecamatan Sintang Tahun 2011. Jurnal Keperawatan Indonesia, 2(3): 156-158

Notoatmodjo, S. (2010). Metodologi penelitian kesehatan. Jakarta: Rineka Cipta.

Sani, A. (2008). Hypertension current perspective. Jakarta: Medya Crea.

Sustrani, L., Alam, S., Hadibroto, I. (2004). Hipertensi. Jakarta: PT Gramedia Pustaka Utama.

World Health Organization Regional Office for South-East Asia. (2011). Hypertension fact sheet. Retrieved from http://www. searo.who.int/entity/noncommunicable diseases/media/non_communicable diseases_hypertension_fs.pdf 